\title{
第123回 大腸肛門病䔲談会
}

\section{直腸肛門病変の画像診断}

\author{
日時：平成 4 年 9 月 12 日（土） \\ 場所 : 社会保険中央総合病院 $4 \mathrm{~F}$ 講堂 \\ 司会：松田保秀先生（松田病院） \\ 大木繁男先生（横市立大学第 2 外科）
}

隅越（幸男・社会保険中央総合病院）それではこれか ら123回の大腸肛門病想談会を始めさせていただきます.

司会は松田病院の松田保秀先生と横浜市立大学第 2 外 科の大木繁男先生にお願い致します.

大末（繁男・横浜市立大学第 2 外科）本日の主題 は 「直腸肛門病変の画像診断」です.

最初に高座病院の鈴木紳一郎先生お願、致します.

鈴木 (紳一郎・高座病院) 今日は肛門科医の立場から 直腸肛門部の超音波画像診断（エコー診断）と各メーカ 一のいろいるな機種について報告致します.

従来肛門周囲膿や痔瘦に対する診断は，指診，触診が 主で験者の経験によるところが多かったと思います。し かし最近ではこの分野にも画像診断が行われるようにな ってきております．さて私どもは1987年から肛門病変に 対して経㨁腸的超音波検查, CT 検查による画像診断も 行い,より正確に病態, 進展程度を把握し, 治療方針を 決定してきました。

肛門病変に対する超音波検查機器には，腹部エコーで 使用する機種に接続できる経直腸用のプローブと内視鏡 の先端に超音波チップをつけた超音波内視鏡がありま す. 前者には直腸肛門管長軸に対し横断面を描出するラ. ジアルタイプ，長軸方向に対し縱断面を描出するリニア タイプ，双方のチップが装着されているバイプレーンが あり，前立腺，直腸癌の術前の染達度診断等を対象に開 発されてきました、今回このいろいろな各社さまざまな 機種を整理し，どのようなプローブがあるかをまとめま したので，紹介いたします．

まずアロカ社のプローブをみますとラジアルタイプと リニアタイプ, バイプレーンのタイプの 3 種のプローブ があります.これはラジアルタイプで, 使用されている 超音波の周波数は $5 \mathrm{MHZ}$ です. 直腸肍門管長軸に対し
て横断面を描出します. 次はアロカのリニアタイプのプ ローブで $5 \mathrm{MHZ}$ ，先端にゴムをから゙せ脱気水を注入し， バルーンをふくらませ使用します，アロカ社のバイプレ ーンタイプのプローブで, 7.5MHZ のリニアの先端に， ラジアル方向に描出する $5 \mathrm{MHZ}$ のコンベックスチップ が装着されており，横断面と縦断面を描出し得ますた だし双方のチップの間に $1 \mathrm{~cm}$ の距離があり，リニアで 描出した病変をコンベックスで横断面として描出すると き，数 $\mathrm{cm}$ 引かなければいけません．以上の中でリ二 アとバイプレーンに穿刺針の使用が可能です.

日立社製にもバイプレーンとリニアがあり，いずれも 穿刺針の使用が可能です．横河にもりニアとバイプレー ンセクターがあります. 東芝には経直腸用プローブと超 音波内視鏡があります。経直腸用プローブは $5 \mathrm{MHZ}$ の リニアタイプと $5 \mathrm{MHZ}$ のバイプレーンタイプがありま す. バィプレーンタイプで, やはりリニアにコンベック スがついています。

東芝のリニアタイプとバイプレーンタイプが接続可能 な超穴波診断装着には超音波内視鏡が接続可能です.

オリンパスの超音波検查機器は内視鏡用のみです．超 音波内視鏡は直腸肛門のみでなく食道，胃にも使用可能 です.

，以上各社の超音波診断装置，プローブにはそれぞれの 特徽がありますので，用途に応して機種選択すればよい と思います．検查に慣れるのには 4，5例でよろしいか と思います．当院ではアロカ社製のバイプレーンを使っ ております。これはIIHA の痔瘦で超音波検查を行うと low echoic な部分があり，これが abscess であること がわかります.

これはIII型の将瘻です，fibrosis 瘏瘦病変では high echoic な像がでると考えられます．すでに超音波検查 
装置をおるちちで直腸用のプローブがないときは，各メー カーからいろいろな機種が発売されて掞りますので，そ れを購入すれば直腸肛門の超音波検查ができると思いま す.

松田（保秀・松田病院 司会）最近では肛門疾患を超 音波検查で客観的に診断し，また超音波画像上で生検を 確実に行うということも行われています.

小西（文雄・自治医科大学外科）私は直腸の腫瘍を主 にやってきましたが，一番問題になるのは解像度がぞれ がいいかということです．現在のところ私はアロカの 7.5MHZ リニア型プローブを用いると層構造が一番き れいに出るという印象を持っているのですが，招考えが あればお伺いしたいと思います。

鈴木 やはりアロカが先行して開発しており，最も良 い画像が得られます。

司会（大木）对象とする疾患たとえば早期癌あるいは 進行癌の深達度やリンパ節診断にはどのプローブがよい でしょうか.プローブの周波数の違いによる特徴をお教 え下さい。

小西 周波数の違いについては，前回の消化器内視鏡 学会で自治医科大学外科の岡田君が発表しました。 7.5 $\mathrm{MHZ}$ と $12 \mathrm{MHZ}$ の超音波内視鏡を比較すると，小さな 早期癌のようなもの，あるいは $\mathrm{PM}$ 澏ぐらいまでは12 MHZ でやった方がいいかというふうに考えています。 しかし，それ以上深い病変では $12 \mathrm{MHZ}$ では超音波の減 衰があり，とりにくいことが明らかです。

司会（松田）次に高野病院の辻先生にご発表和願いし ます。

过（順行・高野病院）肛囲膿瘍，痔瘦，これら疾患の 術後, 肛門周囲膿皮症, 粉瘤, 肛門括約筋機能不全に超 音波検查を施行し，正常肛門と有肛門疾患症例の超音波 画像について検討を加えました．超音波検查で肚門の正 確な謬断を行うためには，まず正常肛門を把握すること が必要々思われますので, 初めに正常肛門症例の解剖の 超音波検查について触れ，その後有肛門疾患の超音波検 查について述べたいと思います。

私はラジアル式超音波検查を使用していますが，リニ ア式と比較すると，縦方向の情報が得にくいという久点 がありますが，それに対しては検查中にプローブを頻回 に引いたり入れたりすることによって，内外括約筋，肛 門举筋の超音波画像より位置を把握することが重要だと 思われます。

これは内括約筋と皮下外括約筋を示し，超音波プロー ブを肛門より挿入直後の超音波画像で，肛門内側よりや や外側に low echoic な全周性の層が認められます。 これが内括約筋を示し，内括約筋は直腸内輪笳の続きで
あり，肛門最下部で反転しているため，その最下部で最 も厚い，またその外側には内括筋同様 low echoic な層 方肛門全周を取り囲んでいて皮下外括約筋を示していま す.

次は皮下外括約筋が描出する位置よりさらに後側に入 れたときの画像です、肛門後方よりU 字に囲んでいる low echoic な層が認められ，浅外括約筋を示していま す.

浅外括約筋の頭側にはまれに low echoic な肚門を円 周に取り巻く深外括約筋が見えることがあります，しか しこれは恥骨直腸筋と近接しているためだと思われます が、はっきり断定される症例は少ないように思われまし た.

次が levator の超音波画像で，こちらが恥骨亘腸筋 で，その上が恥骨尾骨筋です．括約筋の中では最も強大 な力を恥骨直腸筋は持つと言われていますが，超音波で 検查すると，意外と恥骨直腸筋の幅が薄いという印象を 持ちました。

次に肛門疾患に移ります。

有肛門疾患症例の中で超音波画像が最も威力を発揮す るのは，肛囲膿場と凊瘦だと思われます。

その理由は肛門全周にわたって病変の状況が客観的に 観察できることであり，とくに括約笳の病変がわかるこ とです．また肛門膿瘍, 痔掼の原発口の描出が可能です． 肛囲澧湟，痔瘦の根治術の基本は，原発口から原発巣に かけての切除ですが, 術前に超音波険查を施行し，原発 口と原発巣の位置を確認することが病変を根治する上で 非常に重要と思われます，筋閒洔霓の場合，かなり原発 ロがはっきりわかります。

次は肚囲膿湟，II HA の症例です，内外括約筋に low echic で cystic pattern を認め, dentate line より上 で，IHA を示しています.

また anal 側に引いた位置に cystic pattern と認める IILA を示しています.

この症例は浅外括約笳が描出される位置においてて, 浅 外括約筋に沿う形で両側性の bilateral の low echoic の mass を認める症例で， III と䛦断されます，また 浅外括約㘯内側には II HS を認め, 総合診断は IIIBS, IIHS になります。

この症例は肛門挙笳が描出される位置において；肛門 に両側性の low echoic mass を認めるのでVBS 病変 と診断されすす。

またプローブを肛門側に引くと bilateral の病変を認 め，IIIS です. それからその内側を注視しますとここ こに IIHS が見られ，総合診断は IVBS，IIIS，IIHS になります。 
術後の超音波画像です．現在肚团膿瘍，侍璂の術式は 括約筋温存術式が主流で，開放術式は後方の浅い笳閒病 変にのみ適用される傾向にあります．深部病変に対し括 約筋温存術式が施行された場合，手術の大部分は括約箭 内で操作され，この部分は主として触診により術後経過 の観察が行われることになります，ところが術後の診察 は病変の洀痕や疼痛のため, 触診による経過観察が旧常 に困難で，正確な診断が難しくなります。この点で術後 の疼痛や疟痕等に障害されることなく検查可能な超音波 検查が有用と思われをす.

drainage 不足で治癒が遷延する 症例に超音波検查を 進行すると drainage 不足がはっきりわかります.

これはIIIBS，IIHS の症例に括約筋温存術を施行した 例ですが, 術後白血球上昇と疼痛を認め, 超音波検査を 施行しました．10時の方向に drainage 不十分な部分が 見られました。

そして抗生剂投与後の検査では low echoic が消えて います。

次に痔㿉再発について触れます，現在術式の進歩によ り再発症例はかなり減少していますが，いまだ皆無では ありません，II病変のごとく浅い病変の場合情指や触 診で再発の診断は比較的容易ですが, $\mathrm{I}$ 病変, III病変の ような哚い病変になると, なかなか触診等で再発の診断 を下すのは困難です．しかし超音波検查を用いると，再 発症例の場合は cystic pattern が描出され，比較的容易 に診断できます.

これはIIIBS，IIHS に対して括約筋温存術後 1 カ月目 目の症例で, 術後創の治漓は順調でした。肉眼的には㽾 痕に近い状態でしたが，白血球上昇を認めたため超音波 検查を施行しました，後方に cystic pattern を誌め,再 発と診断しました。

次に将瘦様病変の鑑別について触れます．外来診察の 際, まれに痔瘦との鑑別が非常に困難な症例に直面しま す.たとえば肚門周囲の粉瘤や澧皮症症例がそれです. 指診や触診では㘕別に苦虑する場合が 非常にあります が，こういった症例でも超音波検查を施行すると，粉溜 や膿皮症の場合は原発口や原発巣が描出されないため， 容易に痔瘦との鑑別が可能になります。これは肛門周囲 の炎症性粉瘤の症例で，肛門痛と澧汁排出を主訴として 来院しました．指診では 5 時の方向に痔侍の二次口様病 変と同部位からの膿汁の排出を認め, 触診では同部位の 圧痛と硬結を認めました，明瞭な瘦管は認めませんでし たが，白血球は10,400と上昇していました。

そこで超音波検查を施行したところ，原発口と原発巣 の描出はなく, 痔瘦怕否定し, 炎症性粉瘤と診断しまし た. 手術結果も同様でした.
次に括約不全症例の診断と術後の判定について触れま す. 最近, 肛門機能を温存する時代の流れをくんで, 種 々に括約笳温存術が工夫され，施行されるようになりま した. 一方, 従来の主な術式だった開放術は, 括約不全 や soiling の原因となるため，施行症例は少なくなって

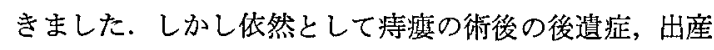
時の外傷, 肛門部外位の後遺症等で括約不全を来し, 便 漏れ，ガス漏れ等で来院する患者は少なくありません. 当院ではこのような症例に対して適当な検査がなかった ために，以前は指診で診断を下してきましたが，超音波 検查を施行すると，括約解断裂が容易に診断できます。

これは 5 年前に他院にて侧方の痔瘦に対して開放術式 を施行した症例で, 術後. soiling が発現し, 当院に来院 しました，超音波を施行すると，内外括約筋の断裂が認 められ，手術を施行しました。

術後ですが，この部位の括約筋の走行が認められます。 このようにして術後の判定も容易にできます.

司会 何か御磒問はございませんか.

岩垂（純一・社会保険中央総合病院）恥骨直腸笳の走 行でちよっと興味樑かったんですが，あれは横断面で見 た場合に後ろの方でU字形になっているという印象があ ったのですが，あれは結構後ろで消えていすすね．あれ むちやんと違う位置になるとU字に。

过 後乃が角度の関係で消えてしまう症例もあるので すが，たとえば体位を変えるとか，挿入角度を変えると かによって，後ろの走行を描出させることは症例によっ て可能です.

岩垂 先生は思ったより恥骨直腸筋は薄いという印象 を.

辻 超音波検查の画像で見ますと，思ったより薄いな といら印象を持ちをした。

岩垂 痔瘦の再発の場合に扔ける超音波診断はいかが でしょうか。

迁 echo で再発を診断する場合, granulation との 鑑別が難しいと思います．痔瘦術後の創の治療過程では まず granulation ができて治ってゆくと思います. echo でみると, high と low との像が混じったような形で 描出されます。そして治湓が遷延している場合，cystic は pattern がでてきます。

岩垂 そうすると echo で描出されない机むかかわら ず再発ということはないわけですね．大体再発は echo でわかるわけです权。

过 III, IV病変では腫瘍がたまるスペースがあるので， echo ではわかりやすいということです.

岩垂 たまらない病変といらのもありますよね.

过 はい，それらの症例に対してはやはり echo だけ 
じゃなくて，その他血液所見とか造影, 触診, 指診等を 入れて, 総合的に判定するのがいいんじやないかと思い ます。

岩垂 肛門膿瘍ではかなり深部になると, 切開排膿を 外来で施行したいわけですが，深部の肛囲膿瘍では指が 届きにくく, どっちの方向に切っていいのか非常に困る ことがあるんです，そこで迁先生は echo 下に切開排膿 を試みられて㧍りますでしょうか，

辻 一番樑部の切開排膿で困るのが，やはり中心がど の位置にあるのか, どのくらいの距離にあるのかわから ないことです.そして切開排澧法局所麻酔下で行います。 もし腰麻酔下にやってしまいますと, 内括約筋, 外括約 筋との緊張が取れるので, 比較的かかりららくなること があるんです。

岩垂 外来で echo 下に切開排蛿註簡単に行うことは 可能です妏.

辻はい，ただ，外来診察の時に行うには十分に時閒 が必要です.

隅越 粉瘤の症例は結構大きな傷がみえましたが，手 術した後ですか.

辻 いえ，全く処置なしの初診の患者さんです．

隅越 普通 atheroma か痔瘦とかいらのは臨床的に肛 内の診察だけでわかるわけですが，先生が提示した症例 は echo で原発口が見えないので粉瘤であるということ を見せるために出したんですね（笑い）。

辻 要するに役に立つということです.

隅越 痔瘎というのはもう中の圠瘦管の組織がずっ

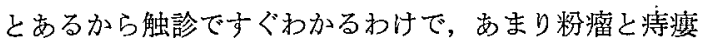
閒違えたことはないんです，それから粉瘤柱，切開する と Atheroma Brei が出て、これは粉瘤だとすぐわかり ます。

西（裕司・西外科・肛門科）膿皮症との鑑別で原発口 が描出されるかどうかとの拄話でしたが，痔瘦の場合， 全部原発口わかりますか.

辻 いや, 全部ではありません。筋間病変が 1 番よく わかりますが，大体 8 割から9割ぐらいは原発口が比較 的明瞭に描出されます。

西膿皮症との鑑別は原発口だけですか.

辻 、ま隅越先生から質問がありましたが，㐫れは膿 皮症にもあてはまり，そういうことで鑑別は十分だと思 います。

西 肍門の近くまでいっておつてもわかる.

辻 要するに超音波の届くレベルというのがあります ので，㐫まり浅い場合には描出されないこともあります。

松田 (直樹・松田肛門科医院) 将瘦とか確かに画像で 出てくるようですが，たとえば rectocele のような病
変は描出できますか.

辻 rectocele の場合は echo そのものだけで確実な 診断は無理だと思います．括約筋の発達が覀いその他に 関してはわかると思いますが，やはり触診, それから defecography で診断を下されたほうが確実だと思いま す.

三木（達・三木肛門科）打忙しいと㧍っしゃっていま したが，1例で時閒はどれくらい，

辻 $1 \sim 2$ 分です.

河野 (一男・松島病院) 再発のときの残留膿瘍とし ての cystic パターンが出たといらことで,われわ礼は筋 充填，IHC なりIIIB なり大きな cavity がある場合， 筋充填をやって抢ります，術後見てみますと，確かに cavity 全部に筋肉弁が入るわけではなく一部なので, 残った部分は cavity はやほり cystic なパターンとして 描出されるわけで， $2 \sim 3$ 力月から 4〜 5力月経つ亡だ んだん小さくなってきます。

ところで発熱があり，白血球の上昇があれば膿場があ ることがわかりますが，白血球の上昇がないとき膿瘍が 增悪してゆくのかどらかが超音波検查で判別できるでし 上らか。

迁われわれは筋肉充垣はほとんどやって㧍りませ ん.しかし施行した少数の症例では mixed か, cystic pattern に映るかということで判定をしています。

重岡（信悟・東京女子医大第二外科）直晹癌に対して 肛門括約筇温存手術を行う場合, 肛内挙筋への癌の浸潤 があるかどうかが重要で, 縁直腸的超音波検查を行って お゙ります，先生の症例では何\%に肛内举筋がみえます か.

过 パーセンテージは出したことないんですが，たと えば高齢の女性の症例なんかの場合には，全体が霞がか かったように白くなってきて括約筋が見えにくいという 症例はあります。ですから全部が全部きれいに映ること はないと思います。

亀岡りニアスキャナーですと $30 \%$ ぐらいなんです が，先生のようにラジアルを使うともう少し上がるでし 上らか。

过りニアから最初私も入っていったんですが，1つ はリニアの画像は解剖学的に非常にわかりゔらいので, あきらめてしまったんです、ですからリニアとの比較は ちよっとわかりません．

司会（大木）次に松島病院の田中先生, 直腸肛門部超 音波画像下生検のビデオを刮願いします.

田中（良明・松島病院）biopsy gun 用いた経肚門 的超音波ガイド穿刺生検についてお話したいと思いま す. biopsy gun, 自動穿刺装置を用いて超音波ガイド下 
穿刺生検を行いましたので，スライドおよびビデオで御 覽いただきます。

スライドは自動穿刺装置，メディコン社製 biopsy gun で，ハンディタイプです．中にバネが入っていま して, バネ力でかなり強力な針の仕込みができます. 穿刺針は太さが18ゲージと20ゲージで，長さは $16 \mathrm{~cm}$, $20 \mathrm{~cm}$ です．私は18ゲージ，20cm を用いて㧍ります。 biopsy gun を用いて穿刺すると，瞬時の動きで前方約 $11.5 \mathrm{~mm}$ ぐらいのところをねらって内筒がまず出て， それを追いかけるようにして時間差で外筒も出ますの で，かなりきれいなコアサンプルが取れます。

マークしている前方約10mm を衫らって打ち出しま す.

実際に肛門指診で肛門部の硬結，压痛を認めた患者に 超音波検查を施行しました。

前処置はグリセりン浣腸 $120 \mathrm{ml}$ で，側卧位の体位をと らせます．穿刺の際には検查前に仙骨ブロックを行って います。

これが超音波プローブで，アロカ社製の SSD 650経 直腸用プローブで，リニア式， $5 \mathrm{MHZ}$ です、その前方に 固定した部分が，アロカ社製 MP 2366穿刺アダプター でこれをプローブに固定し，穿刺ポイントを定めむす。 アダプターに穿刺針をセットし，超音波画像を見なが らプローブをゆっくり進めます。

これが biopsy gun を用いた組織像です、かなりクリ アカットな標本が採取できます。

症例は 45 歳の男性で, 肛囲膿瘍で外来にて切開排膿を しましたが，その後も肚門の 6 時方向を中心として 3 時 および 9 時方向に硬結と压痛のある方です.

ビデオでは内外括約笳，恥骨直腸筋，肛門挙筋，直晹 膨大部等で座骨直腸窝，骨盤直腸窝を区別しています。 6 時位㯰に low および high echoic な部分があり， ここを穿刺します，予め仙骨ブロックを行いますが，患 者さんにはピクッとした衝撃があると話して招きます。

自動穿刺装置 biopsy gun を用いると，超音波ガイド 下に従来より適切かつ正確にねらった生検が可能である ことを報告致いたします.

小西この穿刺の対象となる疾患はどのようなもので しょうか。

田中 現在 malignant のものを疑って穿刺している わけではありません.

本郷（啓之・本郷病院）それで判明したのはどういう 事柄でしょうか.

田中 やはり血液像そのほか炎症所見が白血球等にあ らわれない微細な炎症で, 㾌瘨病変がいまのところ大部 分です．それと区復した手術, 難治性の痔瘦に対して行
つております.

岩垂 よく直腸辺の病変で malignant なものもござ います孙。そういうものに利用するとよいとおむいます が. むっと簡単に注射器にピンク針でもつけて echo下 に穿刺して吸収して取るというのと比べてメリットは何 ですか.

田中 やはり吸引細胞診などですと，かたいものはな かなか取れないと思います。これを用いるとワンタッチ で瞬時にいいところをねらって取れるんです。

岩垂 針がものすごい速い勢いで押し出されて，あと 引っ込むわけですね。

田中 内筒，外筒が出しっぱなしになります．

岩垂 そうすると biopsy したい部分は必ず取れてい るわけですね。

田中はい。

岩垂 ディスポですか.

田中 穿刺針はディスポです.

岩垂 全部で幾らぐらいですか.

田中 針は 5 本で 1 万円前後だと思います。

進藤（零成・東京女子医大第二外科）われわ礼はアロ カ650, リニア型プローブ，クリニーのシュアカットを用 いて平滑筋肉嗹, hemangioma を診断しております。

内田（好司・内田病院）もしかしてもら少し進歩した ら，ope をしないで瘅瘦の原発巣をああいら方法で取れ るという，そういう見通しはいかがでしょうか。非常に 夢みたいかもしれませんが。

司会（松島）リニアとラジアル，両方でやられたこと はありますか.

田中 私は宗だ経験浅いもので，ラジアルタイプは経 験していません.

司会（松島）リニアの方がやりやすいということです 杖.

野口（一成・大場病院）私は約 2 年前にデンマークの Bruel \& Kiaer 社の装置を購入し，肛門疾患の臨床に 応用しておりますので，その概要を発表させていただき ます：

この装置の特徴は発信板は 360 度回転するラジアルタ イプであること，画像がきれいなこと，使用が簢便なこ と, 発売以来コンソールのモデルチェンジがないことな どです. チップの先端で，発信板は直径 $10 \mathrm{~mm}$ で，で $7 \mathrm{MHZ}$ です. 1 分閒に160回転します. 中心からのセン チメートルの距離が書いてありますが，実際肛門管しか 使用しませんから，せいぜい $5 \mathrm{~cm}$ ，時に $6 \mathrm{~cm}$ ぐらいま でです.

超音波画像上位置と同定するのは男性では前立腺，女 性では会陰体 (perineal body, central point) です. 
正常の超音波像を示します． $3 \mathrm{~cm}$ ，㨉入すると粘膜， 粘膜下層，内肛門括約管，また，さらに哚く捚入すると 外肛門括約筋，皮下部，浅部，深部，さらに恥骨直腸笳 がわかります． $6 \mathrm{~cm}$ まで㨂入すると肛門举筋がわかり ます。

これは肛門後方に疼痛を訴えた患者で， $1 \mathrm{~cm} 5 \mathrm{~mm}$ ぐらい入ったところに硬結が触れますが，何かよくわか らない，超音波で見ると low echoic で inflammation があり, cryptitis という診断ができるかと思います。

これは外見上全く变化ありませんが，8時の方向に非 常に疼痛を訴え，abscess．であることは大体推測できる んですが，切るかどうかと．從来ならば punction する んですが，結構痛いので，超音波をすると low echoic でありますが, echo free space ではないので, 炎症の 最中ということで抗生物質を投入して帰します．

これは一見して全然変化がないように見えますが，こ こに大きな硬結があって，非常に疼痛を訴えておりまし た.

当然切開と思うんですが，ぼこを切るかで超音波をや うてみますと, echo free space があるのでここを切開 します。

これも全く変化のない症例ですが，後方に強い疼痛を 訴えます。

ここに free space があり, abscess のயL というこ とがわかります。

この症例では abscess が後方から綎走筋をやや破壊し ていますが，外括約筋は越えていないという所見から IIH といらことがわかります。

これは破壊してさらに後方に及んでいますので型と わかります。

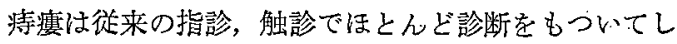
まいますし，手術にも不便を感じません，しかし所見が 明らかでない症例では検查の有用性怔ある之思います。

これは 12 時と 9 時と 6 時，それからこのあたりに有痛 性の硬結を触えます。

この症例では瘦管がはっきりしませんが，超音波検査 でみますと 3 個の瘦管がみえます，この症例では瘦管が 浅外括約竻を貫いています。

もう $1 \mathrm{~cm}$ 上にいくと内括約筋を貫いて， II L である とふかります。

これは非常に樑いところ，2〜 $3 \mathrm{~cm}$ のころですが， 外括約筋を破壊してい宗せんので， IIH であるとわか ります。

これは一見して馬蹄型痔瘦だらうとわかります。

このように超普波で病変を描出しておきますと，一応 手術のデザインの参考にもなるというわけです.
次は27歳の女性で10日前に肛門の後喅側の皮膚が膨隆 してきました，痛みはないが座ると違和感がある，超音 波検查を行うと low echoic な部分があり，をれを穿刺 すると血塊が採取され，血腫と診断されました。

また，血栓性内痔核と肛門周囲膿癔の鑑別に超音波検 查が役立ちます。

司会（大木）次社保中央の奥田先生にお願いしま す.

奥田（哲也・社会保険中央総合病院）超音波内視鏡に よる大腸の検查が普及してきましたが，当施設でむこと しの4月から主に㨁腸癌の術前の患者さんに検查を行 い，術前の媣達度診断を試みています。

装置はオリンパス社の GFUN2 といら機種で，これ は上部消化管機種ですので，それを直腸に流用して使っ ています.ラジアルタイプで7.5MHZです.受信装置は EUN2 を使っています。

これが fiberscope の先端で，そこに回転する超音波 端子があり，その手前に斜視の内視鏡がついています。

先端はバルーンがるくらませるような状態になってい て，場合によってはここに脱気水を注入して使用してい ます.

超音波の端子が粘膜に接した状態ではいい画像が得ら れませんので，ほとんどの場合脱気水を直腸に注入し， 直晹壁を進展させた状態で観察しています，㨁腸が腫瘍 等で非常に狭くなっている場合は，無理に. fiberscope を挿入して乱いてから、バルーンをふくらませたりして 観察しています.

これは最近っくった椅子で，肚門の当たるこの部分が あいていて，患者さんに座ってもらって直腸内に水を注 入して，下の方から肛門内に fiberscope を抨入して観 察しています。

こういら体位で下から fiberscope を挿入して観察し ています.

超音波内視鏡の模式図で；実際に水を満たした内腔が 10W に映って，壁構造が high, low, high, low と大 体 4 層構造に描出され，その不整脈を見ることによって 深達度を診断するわけです。

使っている診断基準で，1 番内腔近い第 1 層が，境 界を含む粘膜固有層の一部. 2 層方粘膜固有層乙粘膜筋 板. 3 層の high のところが粘膜下層で，4層が固有筋 層のところだとなっています．診断として，M：は第 3 層に変化がないもの. SM は第 3 層, 粘膜下層に不整や 中断が見られ，第4層の固有觔層に変化が ないもの. PM は第 3 層が完全に断裂していて, 腫瘍が第 4 層, 固 有筋層に食い込みが見られる，それ以上のもの， $\mathrm{A}_{1}$ 以 上となってしまいますが，第4 層が中断しているとか， 
その外側が不整に見えるとか，そういうものを $A_{1}$ 以上 と診断しています. $\mathrm{pm}$ と $\mathrm{a}_{1}$ の癌の症例の超音波像を 示します．次の症例は下部直腸が腫瘍ですが，前立腺は low echoic であり，腺と直腸あるいは腫場との境界は 超音波検查ではっきりとわかります。

岡田（真樹・自治医科大学外科）先生のところでは直 腸，肛門の超音波検查は座位で行うのでしょうか．

岡田 そうです，患者さんに座っていただき，注腸検 查用のバルーンで直腸内に $200 \mathrm{ml}$ の脱気水を入れます． 足りなければ追加します．検查できる直腸の位置として は下部直腸，上部直腸ぐらいまでです。

黑川 超音波像を見ていると澞の先進部の形がわかり ますので, 浸潤度 $\alpha, \beta, \gamma$ もわかるのではないかと考 えられ，大変興味を持っております。

内山（正一・東急病院外科） CT とか腹壁外の echo なんかと比べて，かなり有用でしょうか。

奥田 経直腸的超音波検查では連続して観察できるの で，非常に小さいものを見るのはいいと思います。

司会 (大木) 直腸進行癌では病変の後側に音響陰影が 出現して深達度がわかりにくいと思いますがいかがでし ようか.

奥田 大きな病変ではプローブの扥入ができなくなる ので，検查やってない場合が多いです．小さな $2 \mathrm{~cm}$ と か $3 \mathrm{~cm}$ の病変に対して検查を行っております.

司会（大木）小さいものがわかりやすい.

奥田 わかりやすいです.

司会 (大末) たとえば前立腺から何 $\mathrm{mm}$ 入ると腫煬 があるので， $\mathrm{EW}$ を何 $\mathrm{mm}$ 残したら切れるとか，そ らいうのはわかりますか。

奥田 今後そういうことをしたいと思っているんで す.

司会（大木）次は東京女子医大の進藤廣成先生に echo 診断についてお願いします。

進藤（廣成・東京女子医大第二外科）私どもでは直腸 癌の壁樑達度とリンパ節転移について, 超音波と CT, MRI を術前に行っています。 まず超音波から沶示しま す. 後で板橋先生に CT, MRI についてプレぜンテー ションしていただきます.

最近直腸癌は癌の進行度に念じて手術式を変えており ます，そのために術前㟝断をかなり䈣しくわれわれの教 室では行っています，これは $\mathrm{Rb}$ の症例で, 経直腸超 音波検查についてはいろなな報告が出ておりますので, そんなに深く説明したくないんですが，リンパ腺がはれ ていることはこれでもわかると思います..これはリンパ 節転移した画像です.

これも $\mathrm{Rb}$ の症例ですが，これが tumor です. 同し
ようにリンパ節がはれているんですが，これは meta で はありませんでした，Bモードでは存在診断ができるん ですが，質的診断がまだ十分ではないと思います．われ われの施設では堂直腸りンパ節に関して 130 例検討し, 84\%ぐらいの正診率があります.

次に上方向のリンパ節について検討しています．これ は大動脈，これは IMA です，おへそのところの大体直 上ぐらいに IMA 根部を描出することが簡単にできま す。いままでの超音波と違うのは，体表用の $7.5 \mathrm{MHZ}$ の端触子を使うことによって，きれいに描出することが できるようになったことです.

最近ではカラードップラーを用いて同じように血流を 見ながら末梢まで追うことが可能になり，リンパ節なの か小さい脈管なのかわからないときなんかは，大変有用 になってきました.

典型的な IMA 根部のリンパ節転移したリンパ節で， 大体 $2 \mathrm{~cm}$ 離れたところに描出されています. $5 \mathrm{~cm}$ らいまでは IMA を描出することができます，

ただ，前のスライドのように大きなリンパ節が IMA 根部にあるというのは少なくて，このスライドのように 小さなリンパ節を描出することが多いわけです。これは 転移して招りました。

これはずっとこの辺が IMA 根部なんですが，ずっと 追っていくとここにリンパ節があり，252番 meta と診 断しました. 病理でも meta でした.

側方について体表からの読影ができるかどうか試みま した.これが iliaca externa です.ここに high echo に二重に見えるのが閉鎖神経でこれは術中 echo とか術 中所見で25例検討し，これが閉鎖神経であることがわか りました．ですから開鎖りンパ節はこの周囲にあると考 えていいと思います。

カラードップラーで内腸骨動脈を描出しているところ

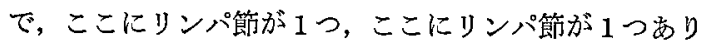
ます。

これは直腸悪性リンパ腫のリンパ節がはれているのを 描出しています.

内腸骨のリンパ節が大体 $1 \mathrm{~cm}$ ぐらいのが描出できま す.

上方向のリンパ節転移を 130 例で検討したんですが， MRI とUS で見ると, やはり体表操作で自由に操作で きるUS の方が正診率は高い.

これは超音波だけの側方りンパ節の転移診断で,262番 ですと specificity は大体 $99 \%$ とかすごく高く, 存在診 断はできるんですが，中直腸とか，ここで282番と272番 を一括して書いてありますが，診断率が落ちてきます．

辻 われわれもよくリンパ節の転移を描出することに 
努めているのですが，先生がおっしやったように必ずし む meta とそれが一致しなくなるんです. 先生の meta の診断基準は.

進藤 文献的には縦横比が高いとか, 内部 echo があ るとか， spoty echo があるとか言いますが，実際やっ てみるとスライドのと㧈り内部 echo む岁るし，縦横比 が高くても meta がないのがあるので，現時点では B モードの超音波ではかからないんじゃないかと思いま す.これから進为ているのは，カラードップラーでわか るかどうか，血流がリンパ節に入っていくのかというこ とを検討してみます。

司会 (大木) 転移は球状に近い.

進藤 普通文献的には球状で縦が長くなってくると。 でも，実際やるそそうでむない，

司会（大木）echo で見える閉鎖神経は術中に確認し ましたか?

進藤 確認しました。

司会（大木）確認したというのは直腸から脱気水をい れるんですか.

進藤 入れません。

司会 入れない.普通だとガスで見えなくなりますが， 何か特別な工夫はあるんですか.

進藤 見えなくなるように思うんですが，実際圧をか けて, compression phobe といいますが，押すことによ วて.

司会 (大木) $3.5 \mathrm{MHZ}$ ですか.

進藤 $3.5 \mathrm{MHZ}$ と $5 \mathrm{MHZ}$ でやっています.

司会（大木）セクターみたいに.

進藤 セクターは分解が悪いんじゃないかと思いま す.

司会（大末）ほとんどの症例で閉鎖神経を見つけるこ とができますか.

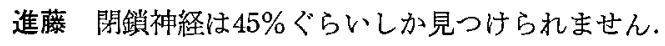

司会 (大木) 総腸骨動脈, 外腸骨動脈, 内腸骨動脈と たどってゆくと血管走行がわかり，経直腸的に内腸骨領 域のリンパ節はわかるように思いますが.

進藤 オリエンテーションがすごく難しいと思いま す，経直腸の場合.

司会 (大木) 内外腸骨動脈の分岐部, echo でわかり ます初，そういうのでいくとわかると思うんですが．

進藤 それがなかなかわからないんです。

司会 (大木) 次何じ女子医大の板橋先生に MRI 診断をお願いします。

板橋（道朗・東京女子医大第二外科）MRI を用いた 直腸癌の壁深達度診断, 傍直腸リンパ節転移診断, 側方 リンパ節転移診断について検討いたしましたので，報告
いたします。

対象は直晹癌手術症例64例で，使用した装置は超伝導 の0.15テスラー MRI 装置および超伝導の0.5テスラー MRI 装置です.

まず壁深達度診断ですが，1番左側，腫富はこの部分 ですが，直腸外壁が平滑なものを PM 以下，直腸外壁 がイレギュラーなものを A1から A2，1番右側，これ も全部腫瘍で，これが前立腺，この直腸周囲の high に 見える白い部分が途絶しているものを $\mathrm{A}_{1}$ 症例として検 討しました。

比較として CT も同時に行いましたが，その成績を 比較すると，MRI では正診率 $82 \%$ ，CT では $76 \%$ です. MRI むCT む両方に言えることですが，ちょっと深く 読み過ぎる傾向が見られ，深達度 PM の症例を媣く読 むといら症例が目立っております。

傍直腸リンパ節転移診断ですが，この症例は典型的な 膀直腸リンパ節昙移症例です. 左側の $\mathrm{T} 1$ 强調画像でこ の部位に low intensity, T2 強調画像のこの部位に high intensity の楕円形の腫溜像を認めます，このようにし てリンパ節転移診断を行いました.

MRI による直腸癌深達度診断の正診摔は $81.3 \%$ であ り, CT $81 \%$, Echo $84 \%$ です.

側方リンパ節転移診断ですが，側方リンパ節を適確に 診断するのは非常に難しいのですが，われわれの教室で は MRI のスライド面を工夫してよりよい診断に努力し ております，上の方のこのスライス面の設定が，以前行 っていた腫瘍部分の画像です. 一方, 下の画像では内外 晹骨動脈が見えますが，この両側をカバーするように連 続スライスを行っています。

このように両側の外腸骨動脈間の連続スライスを行っ て画像を見ると，こちらがお腹側，こちらが背中側で， これが外腸骨動脈，ここに内腸骨動脈が見え，ここに上 殿動脈が見えます．ここにちょっと内腸骨動脈の枝が見 えますが，ここにこう出てくるのが閉鎖動脈，上方から おりてきて閉鎖動脈と一致して平行に走るのを閉鎖神経 と考えております。閉鎖りンパ節の部位ですが，この閉 鎖神経周囲を閉鎖リンパ節を考えて抢ります。

同一人物の一スライス，内側面の所見です．こちらが 腹側. 外腸骨動脈があって，内腸骨動脈が見えます。内 腸骨動脈がおうつきて, 内腸骨動脈の臟器枝の分岐が非 常に明瞭に描出されてお放ります。

実際の症例で，ここに内腸骨動脈の分岐があり，この 辺に閉鎖神経があってこここにこういうリンパ節が見え， 閉鎖リンパ節転移症例と思われます。

同時に横断像も行っていて, 先ほどの症例は横断像で は見えなかったんですが，この症例は横断像でリンバ節 
が描出されました．左側，これが閉鎖筋ですが，内閉鎖 筋の内側の部分, $\mathrm{T} 1$ 強調画像で low, T2 強調画像で high のリンパ節が描出されています，この症例をわれ われが行っている枝綐横像で見ると，同じうに外腸骨 動脈があり，内腸骨動脈がきます。内腸骨動脈がこのよ うに分岐し，この分岐のところに，ここの周团にあたる ものを中直腸動脈後リンパ節転移としました。

同様に中直腸動脈後リンパ節転移症例だと思います が, これでは内腸骨動脈臟器枝の分岐が非常に明瞭に見 え,ここに小さなリンパ節が何個か見えます.

以上，側方リンパ節について従来行っていた MRIの 通常の横断像，われわれが行った骨盤側枝綎断像，従来 の CT の成績を比べてみました，そんなに違いはない んですが， 1 番のポイントは sensitivity が 4 例中 4 例, 100\%と非常に高く, 他の MRI の横断像, CT と比べ ても非常化高い值を示しています。

辻 当院でも考えているものですから参考に聞かせて いただきたいんですが，はずれた原因を全体的に聞かせ ていただければ。

板橋 順番に怙話しますが,壁深達度に関しては MRI 非常にいいと招もいますが，どうしても Rs，ちょう ど直腸が曲がってきますので，その場所になると普通の 横断像を行っていると，腫煬部分に重直にスライスされ ませんから，それがかなり診断率の落ちる原因になって いると思います，実際に Rs と Ra，Rb と分けて検討 してみると， うちの症例でも Rs では60\%ぐらいの正診 率しかありません：逆に Ra， Rb ですと， CT では $\mathrm{Ra}, \mathrm{Rb}$ の前壁の骖断が非常に悪いのに比べて，MRI ではよい正診率を保っています。

旁直腸リンパ節転移ですが，今日㧍示しした MRI の 成績は 0.15 テスラーと 0.5 テスラーと両装置を用いた成 績で，0.15テスラー装置の解像力が非常に覀く,0.5テス ラーと比べると見劣りがするような状態です、現在はさ らにいい機種に変わっているんですが, 解像力の悪い機 種があったために，全体的に下がっています，実際のリ ンパ節の大きさは，芳直腸に関しては1番小さいものは $4 \mathrm{~mm}$ ，大体 $5 \mathrm{~mm}$ から $6 \mathrm{~mm}$ 西机ば描出できるんじゃ ないかと考えています。

側方に関しては，ほぼ大体の症例で描出はできると思 います．われわれの教室でやはり描出できたのは，1番 小さいのは $4 \mathrm{~mm}$. 大体の描出はできるんですが， echo と同じように質的診断がかなり閣題で，それはこれから 造影剂だとかそういうものを考えて，質的診断にもうち ょっと役立つものを開発する必要があると思います．

内山 MRI はすごく有用だと思いますが，リンパ節 転移は何 $\mathrm{cm}$ ぐらいからわかりますか.
板橋 われわれのいまお示しした症例の中では CT で1 番小さいのは, 傍直腸では $6 \mathrm{~mm}$, 側方では $8 \mathrm{~mm}$ でないと出てきませんでした，側方で MRI では，通常 の横断像では $6 \mathrm{~mm}$ ，われわれが行っている縦断像で 4 $\mathrm{mm}$.

内山 MRI の方が多少.

板橋 そうですね。 それから 1 番いいのは，血管系と の位㯰関係が非常に見やすいことだと思います.

内山 造影剤は.

板橋 使っていますが，それじゃ造影郕使ったから非 常によかったといらことは、いまのところ出ていません．

司会 (大木) 次に自治医科大学の消化器外科の劉先生 に扮願いします。

劉（慶華・自治医科大学消化器一般外科）大腸超音波 内視鏡検查，EUS における誤診例の検討です。

直腸癌の術前に抬ける媣達度猃断は, 治療方針の決定, 特に手術術式の選択という点で重要です，今回私たちは EUS による深達度診断の誤診例の原因を明らかにする ために, 、ままでの EUS 症例を検討しました. 対象は 1989年 4 月から 1992年 6 月までに，当科で施行された大 腸 EUS 症例101例のうち今回の検討に適当と考えられ た 49 例です. 内訳は直腸癌 43 例, $\mathrm{S}$ 状結腸癌 6 例です. 使用した超音波内視鏡装置はオリンパス CF-UM3です. プローブの周波数は $12 \mathrm{MHZ}$ ならびに7.5MHZ です.

これは EUS 診断と病理診断の関係を示し，49例中 40例で EUS による深達度彰断と摘出標本の病理診断が 一致し, 正診率は $81.6 \%$ です. 誤診率 9 例のうち， 5 例 は EUS 診断が病理診断より染く判定した over-assessment の症例で，4例は浅く判定した under-assessment の症例でした． 哚達度による正診率はスライド右に示す 通りで, 明らかな差は認めませんでした。

誤診例 9 例の一覧で，右に誤診の原因と考えられた理 由が書いてありますが，これについて説明します。

誤診の原因として考えられたのは，1．mimi-invasion，2. 炎症細胞浸潤， 3 . Ip または Ips の形状でし た. mimi-invasion といらのは, 病理組織標本上 $\mathrm{sm}$ や $\mathrm{pm}$ をこえる幅 $1 \mathrm{~mm}$ 以下のわずかな浸潤像や脈管 侵警を意味しており，これを EUS でとら光られなかっ たことが誤診の原因となったものです．したがって mini-invasion の症例はすべて under-assessment の症例 です.

炎症細胞浸潤というのは, 癌組織周围の炎症細胞浸潤 を EUS では癌組織と区別できず，炎症細胞浸潤像まで を癌ととらえたため，誤診したと考えられ，したがって これは over-assessment の症例です. Ip また注 Ips の 形状というのは，有菱性また注有茎性 polyp では, 粘 
膜管板と粘膜下層が病変部に引き込まれ，1つの細い線 上の構造として認められるため，M から $\mathrm{SM}$ かの判断 が困難となるものと考えられました。

9 例中 2 例は誤診の原因が明らかではありませんでし た. 次に症例を供覧します。

直腸 $\mathrm{S}$ 状結腸部 $\mathrm{n}$ 長径 $2 \mathrm{~cm}$, II 型の癌の症例で $\mathrm{mi}$ ni-invasion のため樑達度が under-assessment となっ たものです，超音波上，固有筋層を示す低 echo 層は腫 湯部でやや肥厚していますが, その外側縁はスムーズで， EUS の診断は PM 澞です.

そのルーペ像で，癌浸潤は大部分固有筋層に限局して いますが，腫瘍中央部において脈管侵襲の形で固有笳層 外に浸潤を認めます. 病理診断は深達度 ss でした。こ れは脈管侵襲です。

下部直腸の最大径 $2.2 \mathrm{~cm}$ のI型の癌の症例で，炎症 性細胞浸潤のため深達度診断が over-assessment となっ たものです．超音波上高 echoを示す SM 層が腫珸中 央部において明らかに断裂し，EUS による深達度診断 は PM です。

そのルーペ像で，腫瘍は粘膜下層に限局し，その癌浸 潤の先進部に固有筋層に達する中等度の炎症細胞浸潤を 認めます，病理竛断は深達度 $\mathrm{sm}$ です.このようにこの 症例では，炎症細胞浸洞が over-assessment $の$ 原因と考 えられました。ここに炎症細胞があります。

これは下部值腸の最大径 $2.3 \mathrm{~cm}$ のII型の癌です。こ の症例は炎症細胞浸潤と固有筋層の断裂が over-assessment の原因となったものです. 超音波上 PM 層が断裂 していると判断され，EUS の梁達度診断は A1です.

そのルーペ像で，癌浸洞は固有筋層にとどまっていま す．原因は不明ですが，固有筋層は断裂しており，炎症 性細胞浸潤が固有筋層外の組織化まで認められます。
これは S 状結腸の亜有蒸性の polyp 状の病変です. 超音波上高 echo の SM 層が狭い頻部から病変部に向 かって引き込まれており， EUS 上 M か SM の判断: が困難で，SM 層が薄くなっているように見えたため， 深達度 sm と判断されました。

そのルーペ像で，標本が長軸方向にきれいに切られて おらず, EUS 画像との正磪な対比はできませんでした が，腫瘍は粘膜層にとどまっておう，組織学的には $\mathrm{m}$ 癌 でした

以上，われわれの EUS による直腸腫場の深達度診 断の結果を示し，誤診例についてその原因となった因子 について検討いたしました。

司会（大木）炎症性のそういった浸潤と癌の浸潤を， echo 上区別するのは難しいということですね.

小西 そういうことなんですが，どうしても癌の周囲 に炎症を伴っている症例が結構あるのですから，そうい うのはやはり over-assessment してしまうのは避けられ ないんじゃないかと思っています。

司会 (大木) 全体の正診率は.

小西 全体で $81 \%$ ぐらいです.

司会（松島）本日は非場に難しい問題がいっぱいあり まして，いままでわれわれが肛門疾患を扱っている場 合, 指での診断というのは本当に数字で出てくるという 上り，めるいは絵で出てくるという，そういうところで の切り換えといらのもやらなきやだめだと思っておりま す. また大腸癌のほうの, とくに直腸癌の媣達度のこと についても，MRI というリンパ節の1つ1つがもう完 全にはっきり出てくるという，そこまで性能もよくなっ たし，読影の方もよくなって，理解できるようになって きたのでまだまだこういう問題点というのは発展して くると思います。 